\title{
Stage Metaphors in Verdi's Otello: Miloš Wasser- bauer's State Theatre Production (Brno 1967) in the Context of Otello's Staging Tradition ${ }^{1}$
}

\author{
Šárka Havlíčková Kysová
}

Operas based on the plays by William Shakespeare are a permanent part of the repertoire of prominent international opera houses, even today. The Shakespearian operas by Giuseppe Verdi, i.e. Macbeth (1847), Otello (1887) and Falstaff (1893), are staged regularly throughout the world. This article focuses on Otello ${ }^{2}$, Verdi's penultimate opera with libretto by Arrigo Boito. ${ }^{3}$ I demonstrate that the fusion of the imagination of Verdi and 'the Bard' bring particular cognitive demands to the process of staging, and to the perception of a theatrical performance. Since the methodological apparatus of the article is inspired by the cognitive approach, and especially by Conceptual Metaphor Theory (CMT), the article deals with the process of creating stage metaphors rooted in the libretto of the opera Otello, and in the original Shakespeare play, Othello.

The first part of the article deals with the stage metaphors that Arrigo Boito's libretto 'inherits' from Shakespeare's play. The second part focuses on some essential elements for staging which are rooted in Otello (including the music score). The third part of the

1 The article is based on author's ongoing research focused on the operatic production in Brno, former Czechoslovakia, in the 2nd half of the 20th century. The research project titled 'Generation of Miloš Wasserbauer, the theatre director, and progressive dramaturgy of State Theatre in Brno' is supported by the Czech Science Foundation (project No. GA15-06548S).

2 In this article, I spell the name of the character with ' $h$ ' ('Othello') but in referring to the opera and its mains charakter I use Italian spelling of the title: Otello (without 'h').

3 Otello was first performed at the Teatro alla Scala on the 5 February 1887 in Milan. Verdi composed three operas based on the plays by W. Shakespeare. Macbeth was the first Shakespeare's play that Verdi adapted for the operatic stage. It was staged for the first time in 1847 in Teatro della Pergolla, Florence. (Almost twenty years later, Macbeth was revised and expanded in a French version and presented in Paris on 19 April 1865.) Libretto was written by Francesco Maria Piave. Otello was Verdi's second Shakespearian opera. The third - and the very last opera composed by Verdi - was Falstaff in 1893, based on the play Merry Wives of Windsor and scenes from the both parts of the play Henry IV. Falstaff was adapted also by Arrigo Boito and it is usually considered as Verdi's only buffa (apart from his early work Un giorno di regno). The opera was premiered on 9 February 1893 in Teatro alla Scala, Milan. 
article analyses the staging practice of Otello with special regard to one particular example directed by the outstanding Czech theatre director, Miloš Wasserbauer, in 1967. Wasserbauer's production is compared with earlier and later productions depicting the main stage metaphors, which are recurrent throughout the more than one hundred year long tradition of the staging of Otello.

My general aim is to show that the success of a play's adaptation into an opera is based on the ability to perceive and correctly express the key conceptual metaphors connected to the original play. Artists and directors should be able to properly transform the conceptual metaphors into a work of art, if they want it to be properly and sufficiently processed by the cognitive abilities of the audience or 'perceivers'.

The theoretical frame of this study is mainly based around CMT as devised by George Lakoff and Mark Johnson in Metaphors We Live By (1980). The theory has been elaborated further by the same authors and by other scholars from various scholarly disciplines. The methodologies of cognitive studies are not often used in theatre studies discourse. My aim is to provide an analysis that can serve as an example of theatre studies research using the apparatus of cognitive studies.

The main conceptual metaphor (or image schema) I focus on in this article is containment - in its different manifestations. I use the ontological metaphor BODY IS CONTAINER and metaphors which are connected to this concept, and which express the core of the plot on the conceptual level, i.e. the destruction of a strong body (and mind) by poison. In this article, I deal with a particular example: an operatic adaptation of a play and its staging tradition. Therefore, I discuss two different works and one performance: Shakespeare's play, Othello (1603) and Verdi's opera, Otello (1887), and one particular production of the opera. As they share a common storyline, they also share several metaphors and conceptual metaphors. These metaphors appear at the textual level and are verbalised in both the sung and spoken word. ${ }^{4}$ I will also show that the particular conceptual metaphors of the two different versions of the story can be expressed by means other than language - especially through music and scenography.

In treating the topic, I consider some more general questions: What is the relationship between the traditional view of metaphor in the context of theatre studies, and the theoretical view of the metaphor in CMT? Is CMT able to assist in explaining how the stage metaphor works? I demonstrate that stage metaphors are based on the chaining and associating of conceptual metaphors. Furthermore, I focus on how this manifests in different elements of theatrical and operatic performance.

In CMT, a metaphor expresses an abstract concept via a more concrete concept. It transports the concept from one domain (source domain) to another (target domain) to conceptualize it. The aim is to assist in understanding abstract ideas via more concrete ones, which are usually more familiar.

4 It is not my intention to solve the question of adapting the story by translation from one language into another in this article. To treat the topic demands particular attention and it would be an aim of another article. 
The notion of stage metaphor is not based on a particular theoretical concept. The term is used to explain how stage reality (speech of the characters, props, scenography etc.) refers to the space and reality of the drama/fiction. Furthermore, the term is often used in performance analysis to describe the methods of expressing a particular idea. It is also used in the press, sometimes vaguely, in evaluating the overall quality of performance - in the reviewer's opinion of whether the stage metaphor was or was not comprehensible.

\section{Metaphors in Othello and Otello}

It is well known that - because of their ideas, aesthetics and artistic qualities - Shakespeare's works were treated with great respect by Verdi. Verdi always tried to adapt 'the Bard's' works for the operatic stage as authentically as possible. The programmes for the Czech productions emphasize Verdi's warm and respectful relationship with Shakespeare's work. ${ }^{5}$ Verdi also considered, but never realised, operatic adaptations of two other plays by William Shakespeare - Hamlet, and King Lear. Verdi even made a draft based on King Lear (Re Lear) but finally abandoned the project.

The libretto of Otello underwent several changes. Verdi was interested in Boito's original draft of the libretto but didn't agree to compose the opera until Boito rewrote it. Once both Verdi and Boito were satisfied with the text, Verdi started to compose the music. ${ }^{6}$

Perhaps the most obvious and the most substantial difference between the play and the libretto is the omission of Act I of Othello, set in Venice. ${ }^{7}$ But crucial elements from Act I are incorporated into Boito's libretto, including the leading metaphors, and some motives (e.g. the description of origin of the relationships between the characters).

In Act I of the play, the main character, Othello, is described by his physical appearance, his character etc. not just literally, but also, and above all, metaphorically. Iago introduces Othello, describing him prejudicially in his dialogue with Roderigo. The dramatic situation is set by Iago. Among the first metaphors used in Shakespeare's text is that of the night hunt for a wild animal, devil, ${ }^{8}$ savage, beast. The search for a 'stranger' who had committed the crime of theft. He had stolen Desdemona, the white daughter of Brabantio (1.1). Moreover, Othello is accused of being a sorcerer who must have used - according to Brabantio - some magic or 'drugs or minerals' (1.2.74) to seduce

5 E.g. in the programme from the production in 1989 Evžen Zámečník claims 'Shakespeare was his [Verdi’s] biggest idol' (ZÁMEČNÍK 1989: unpag.) and another Czech theatre director Václav Věžník, Wasserbauer's co-worker, claims that Verdi really loved Shakespeare (HAVLÍČKOVÁ KYSOVÁ 2015).

6 Ref. e.g. to (ZÁMEČNÍK 1989).

7 For discussion about the issue that Shakespeare would also have omitted the first act of his play ref. e.g. to (HONIGMANN 2015: 62).

8 The metaphorical expressions from the verses of Shakespeare's play are emphasised in italics, the words or phrases that I just quote are in quotation marks. If I refer to particular verse I use the edition by E. A. J. Honigmann (2015). 
Desdemona. At this moment, Brabantio describes him as 'thief' (1.2.62) $)^{9}$ and objectifies him as 'such a thing' (1.2.71), despite him being Othello's friend. Furthermore, he comments on the impossibility of Desdemona's voluntary affection for Othello according to Brabantio such a relationship would be 'in spite of nature' (1.3.97) and 'against all rules of nature' (1.3.102) etc.

In several parts of the scene, torches are used to illuminate - to literally and metaphorically 'shed light on' - the scene of the crime. Shakespeare's Act I Scene 1 concentrates on a manhunt that is provoked by two 'enemies' of Othello (Iago and Roderigo) and further encouraged by Brabantio. Othello lets the hunters catch him and proudly admits responsibility for the purported crime. He declares himself to be a man of honour by publically expressing his true feelings for Desdemona. He also declares his honourable intentions towards her, as at that moment, they are already married. The situation is resolved peacefully. But some prejudices prevail. For example, Iago refers to Othello's (the Moor's) 'changeable will' (1.3.347) and with Desdemona's supposed dishonest nature as a woman from Venice. ${ }^{10}$ These prejudices are ready to be used again when Iago requires them.

Thus Iago's relationship with Othello is established and displayed. Roderigo also expresses his feelings towards Desdemona as well as his dashed hopes. Against the prejudices based on Othello's ethnic origin, the main character is characterized as a brave and skilful warrior, and a man of honour. The origin of his and Desdemona's love is described by Othello when addressing the Duke (1.3.129-70). Otello's declaration of love is transformed into the well-known love duet in Act I Scene 3 of Verdi's opera. ${ }^{11}$

Boito's libretto opens with the people of Cyprus (chorus), waiting for their master the hero Otello - who at that time is out at sea in a tempestuous storm. The openings of both Othello and Otello present their audiences with different situations - a hero being hunted and a hero in a dangerous storm - and hear language from two different forms (dialogue in the play, and the singing of the chorus in the opera).

The beginning of Boito's libretto coincides with Act II of the play. ${ }^{12}$ It begins in the midst of a violent storm on the coast. The fact that Boito omitted Act I of the play does not mean it is a mere adaptation of the next four acts. Charles Osborne comments on Boito's transformation of Shakespeare's play as follows:

9 In the context of 'stealing' Desdemona.

10 E. A. J. Honigmann (2015: 9) explains the '[...] fact that was taken for granted by Shakespeare - that Venice was the pleasure capital of Europe, especially in its sexual tolerance' and emphasizes the city's and the women's bad reputation for sexual licentiousness. A Venetian courtesan and fashionably dressed Venetian woman (both expensively dressed) could be 'indistinguishable in clothes and manners. This point, though not made in so many words in Othello, is used by Iago with deadly effect. Venetian wives look and behave like courtesans.' (2015: 10) Honigmann ads that Othello begins to waver because Desdemona happens to be Venetian, so there's no reason for her to be any different.

11 In the duet Othello and Desdemona recapitulate the Othello's warrior past and the dangerous situations preceding their present life in love embracement. Shakespeare's lines in the play which Othello addresses to Duke (1.3.168-9): 'She loved me for the dangers I had passed / And I loved her that she did pity them' are transformed in Boito's libretto - sung by Othello and echoed by Desdemona: 'E tu m'avavi per le mie sventure / ed io t'amavo per la tua pietà.' (OSBORNE 1974: 34)

12 Shakespeare's play is divided into 5 acts, Verdi's opera in 4 acts. 
It cannot have been an easy task to transform Shakespeare's Othello into an opera libretto, but Boito managed it brilliantly. He stripped the play into its essentials, perhaps even to less than its essentials, knowing that Verdi's music would add another dimension, would restore the poetry of the original. It is also, formally, more attractive than Shakespeare's play, not least because its structure in four uninterrupted acts is more compact than Shakespeare's rambling five-act division into fifteen scenes. (OSBORNE 1974: 13)

Furthermore, Osborne emphasizes that in general, 'Boito has been faithful to Shakespeare's conception of the characters' (OSBORNE 1974: 13). This claim is very important in the context of identifying the leading conceptual metaphor(s) of the plot - both of the play and of the opera. The 'stripping the play into its essentials' by Boito, as mentioned by Osborne, can be seen in the context of the correct reception and expression of the essential conceptual metaphors of Shakespeare's play. In the history of the interpretation of the play there are the usual explanations of the plot. It is most often interpreted as a tragedy of jealousy. This jealousy was often connected to the ethnic origin of Othello: he is jealous because he is 'the Moor' - the Muslim. A more recent interpretation emphasizes jealousy but does not connect it to Othello's ethnic origin. Walter Felsenstein, the outstanding opera director of the $20^{\text {th }}$ century (who probably also influenced the work of Miloš Wasserbauer), expresses the opinion that in neither Shakespeare's play nor Boito's libretto, is Othello jealous by nature (KRANZ 2008: $7 \mathrm{~min}, 20 \mathrm{~s})$. The conditions of his life, his destiny and his situation made him jealous - with the great help of Iago.

Othello is a brave war hero who has overcome great dangers and fought many battles. His happiness lies at home - with his wife. In the play and opera, his home is the island of Cyprus. He feels safe there. But one of his closest friends is constantly and secretly leading him to destruction. It is Iago who poisons his master's will/soul/mind with jealousy using subterfuge. In the end, Iago is successful.

These main features of the plot are rooted in a group of conceptual metaphors which can be found in both the text of the play and libretto, and in Verdi's music.

As examples, I will focus on the principal and interconnected metaphors based on following conceptual metaphors ${ }^{13}$ :

1) Three containers:

THE HOME (ISLAND OF CYPRUS) IS CONTAINER

(Otello's strong) BODY IS CONTAINER

(Otello's) MIND IS CONTAINER

2) The metaphor of internal and external battle or fighting conceptualized via

RELATIONSHIP/INTERACTION IS BATTLE/FIGHTING; 
3) The JEALOUSY IS POISON versus the metaphors JEALOUSY IS DISEASE which are connected to the concept of a BODY IS CONTAINER;

4) The metaphor of fall or destruction of the BODY AS CONTAINER;

5) Othello's Story/Actions is (conceptualized as) FAll, as a destruction of the CONTAINER.

\section{Three CONTAINERS and the Metaphor of Internal and External Battle or Fighting Conceptualized via RELATIONSHIP/INTERACTION IS BATTLE}

The explanation of the interactions of the main characters can be based on the metaphor of containment discussed mostly by Lakoff and Johnson in the context of ontological metaphors in their fundamental work on cognitive studies (1980). It is further developed in their other works in the context of the topic of image schemas (e.g. JOHNSON 1987). Besides Lakoff and Johnson, many other scholars have contributed to the debate on this subject. In the field of theatre studies, Bruce McConachie has provided a vital contribution to this topic (2003).

The origin of the INNER and OUTER BATTLE OR FIGHTING metaphor (derived from the conceptual HOME/BODY/MIND IS CONTAINER metaphors and INTERACTION IS BATTLE OR FIGHTING metaphors) are rooted in the play - in its location of Cyprus, the island (CONTAiner) is relatively distant from Venice, Desdemona's former home. It is worth emphasizing that the first act of the play (action omitted by Boito), is located in Venice, while the other four acts take place in Cyprus. Otello is presented as an experienced warrior and war hero who has defeated armies and averted the Turks. In Boito's libretto he makes an impressive stage entrance after surviving a wild sea storm. He is very capable and equipped to defeat an enemy, as long as the enemy is external. He is defeated by hidden (internal) poison or disease. An enemy that he is unable to fight. An enemy that he is unconscious of for most of the duration of the play/opera. He considers himself safe on his home island of Cyprus (CONTAINER). He also thinks that his mind (CONTAINER) is safe because it resides inside his strong body (CONTAINER). If there is any threat, it seems to come from the outside, not from within the 'enclosed' and safe area of the island or from within the hero's body.

The containment metaphor works as the fundamental background for the plot of Shakespeare's play. Boito congenially apprehended this idea. The main topic of the opera is based on the conceptual metaphor. Firstly, the HOME/CYPRUS IS CONTAINER is saved from an external threat. The CONTAIner is not destructed, and stays untouched. Secondly, the threat (Iago's actions) gradually enters another CONTAINER, (Otello's) BODY, it is not averted; and continues to the 'third' CONTAINER, Otello's soul. 
Boito also uses the metaphors of POISON and DISEASE which spread from within the hero's body and destroy/defeat the hero internally. It is worth asking who or what causes the DISEASE in order to infect the strong hero, how does the DISEASE affect him?

\section{lago and the Conceptual Metaphors JEALOUSY IS POISON and/or JEALOUSY IS DISEASE Destructing the Body (CONTAINER)}

Boito faithfully follows Shakespeare's conception of the characters. Nevertheless, he puts a special emphasis on the character of Iago. It almost seems as though Iago should be the main character of the opera. Verdi actually first intended to name the opera after Iago due to his interest in the psychology of the character. He subsequently decided to keep Shakespeare's original title in naming the opera Otello. Despite the fact that it is Iago who 'pulls the strings', the burden of the action itself lies with Otello. ${ }^{14}$

Evžen Zámečník, in his commentary on the opera (from the programme for the 1989 Brno production) describes a very common metaphor comparing Iago to the 'evil spirt who set everything in motion'15 (zlý duch, který vše uvádi v pohyb). In another programme from the production in Brno (1939, directed by M. Wasserbauer), Iago is characterised as a 'dark demon' (temný běs) (BALATKA 1939: unpag.).

Iago acts in secret against Otello. ${ }^{16}$ He causes the 'disease' to start and to spread inside Otello's mind. Otello's mind is affected (poisoned/inflicted) from the outside. The poison/disease affects his body and mind through his senses. ${ }^{17}$ Iago endangers Otello by inducing a threat that can operate from within Otello's mind and body. The disease must be planted into the hero then 'cultivated' from the outside. Considering the containment conceptual metaphor, Iago causes the disease which destroys the CONTAINER from within. 'Within' means that Iago's actions and machinations take place on Cyprus, which is the 'safe' and enclosed home island of Otello (CONTAiner). More importantly, Iago acts from the inside of their putative friendship, which is based on their former army careers. And lastly, Iago acts from within Otello's mind (CONTAINER). Iago 'entered' Otello's mind, through the gates of the senses of his body (CONTAINER), because Otello considers him to be his truthful adjutant and friend. Neither war nor sea-storm is the cause of Otello's downfall and death. The plot outlines a model of destruction of the hero from within the CONTAINER, while the threat awaits far outside the CONTAINER.

Indeed, from this point of view, it is Iago who acts as the main character of the whole story. Why does he do it, what are his motives to spread the disease? Hatred: Iago hates Otello.

14 Honigmann also discusses the possibility of alternative title of Shakespeare's play, The Tragedy of Iago, in the context of change of emphasis (HONIGMANN 2015: 59).

15 For a brief but interesting discussion about the title and the 'real' central character of the play and the issue of a change of emphasis see (HONIGMANN 2015: 59).

16 In the first act (1st scene) of Shakespeare's play Iago describes the mask which he wears when serving Othello.

17 I discuss this topic in more detail below. 
There are several reasons for his hatred - e.g. 'the otherness' of his master (his different race), or even Iago's suspicion that Otello seduced his wife. The reason is not that important. The crucial fact is that Iago hates Otello and wants to destroy him, i.e. to destroy the object (CONTAINER) of his hate. Boito 'extracts' Iago's point of view (and motivation) from several parts of Shakespeare's play. The manifestation of Iago's attitude and his worldview is conveyed through his 'Credo' aria, taking place in Act II Scene 2. In 'Credo' ('I believe') he expresses his attitude to the world and the motivations for his deeds. ${ }^{18}$ Iago expresses his attitude toward Otello, and his evil intentions, not only in the dialogues with Roderigo or Montano, but also - and more openly - when he speaks to himself. This fact is of great importance, especially in staging, as I show with examples below.

From the point of view of CMT, Iago's speeches, usually monologues, are worth analysing. For example, in the play there are the BODY IS GARDEN and WILL IS GARDENER metaphors.

BODY IS GARDEN and will is GARDENER metaphors help explain Iago's actions. They frame Iago's focal point. He denies the influence of God's will on human life. Human deeds (fruits of the gardening of his will) rely on someone's will. Iago's fruits are deliberately bad and dangerous for others. But at the same time he hopes to harvest some goods for himself. Iago's DEEDS ARE FRUITS. Some of them are poisoned, and he cultivates them deliberately.

These conceptual metaphors are very important in connection to the creed expressed in the opera, especially in the context of nihilist or at least blasphemous interpretation of Iago's attitude. These following lines from Shakespeare's play are primarily addressed to Roderigo to calm his emotions when he loses hope of Desdemona becoming his wife.

IAGO: Virtue? a fig! 'tis in ourselves that we are thus, or thus. Our bodies are gardens, to the which our wills are gardeners. So that if we will plant nettles or sow lettuce, set hyssop and weed up thyme, supply it with one gender of herbs or distract it with many, either to have it sterile with idleness or manured with industry - why, the power and corrigible authority of this lies in our wills. If the balance of our lives had not one scale of reason to poise another of sensuality, the blood and baseness of our natures would conduct us to most preposterous conclusions. But we have reason to cool our raging motions, our carnal stings, our unbitted lusts; whereof I take this, that you call love, to be a sect or scion. (1.3.320-33) 
This speech can be, and usually is (e.g. by HONIGMANN 2015), interpreted as an allusion to Saint Paul's letter to Galatians, since the gardens probably refer to 'whatsoever a man soweth, that shall he also reap' (Gal. 6:7). Iago's speech can be considered a mock sermon that uses theological commonplaces - such as the good Christian as a gardener (HONIGMANN 2015: 156).

Boito went even further. The blasphemy develops in Act II Scene 2 of the opera with Iago's aria which can be understood as an allusion to a religious credo. When Iago sends Cassio to ask Desdemona for help, he stays alone and sings his aria addressing God (indirectly and obviously insincerely):

\section{IAGO: $[\ldots]$}

I believe in a cruel God, who has created me

in his image and whom, I hate, I call upon.

From some vile germ or base atom

was I born.

I am evil

because I am a man;

and I feel the primeval slime in me.

Yes! This is my creed!

I believe with a firm heart,

just as does the young widow in church,

that the evil I think and which from me proceeds,

was decreed for me by fate.

I believe that the honest man is a mocking buffoon, and both in face and heart,

everything in him is a lie:

tears, kisses, glances,

sacrifice and honour.

And I believe man to be

the sport of a wicked fate

from the germ of the cradle

to the worm of the grave.

And after this derision comes Death.

And then?

Death is nothingness.

Heaven is an old wives' tale. ${ }^{1}$

\author{
IAGO: $[\ldots]$ \\ Credo in un Dio crudel che m'ha creato \\ simile a sè e che nell'ira io nomo. \\ Dalla viltà d'un germe o d'un atomo \\ vile son nato. \\ Son scellerato \\ perchè son uomo; \\ e sento il fango originario in me. \\ Sì! questa è la mia fè! \\ Credo con fermo cuor, \\ siccome crede la vedovella al tempio, \\ che il mal ch'io penso e che da me procede, \\ per il mio destino adempio. \\ Credo che il giusto è un istrion beffardo, \\ e nel viso e nel cuor, \\ che tutto è in lui bugiardo: \\ lagrima, bacio, sguardo, \\ sacrificio ed onor. \\ E credo l'uom \\ giuoco d'iniqua sorte \\ dal germe della culla \\ al verme dell'Avel. \\ Vien dopo tanta irrision la 'Morte. \\ E poi? E poi? \\ La morte è il nulla. \\ È vecchia fola il Ciel.
}

(OSBORNE 1974: 38-9)

He believes 'with a firm heart' (con fermo cuor) that his evil thinking, and the evil he produces is driven (adempio) ${ }^{20}$ 'by [his] fate' (per mio destino).

19 Translation by Charles Osborne (1974: 39)

20 Osborne (1974: 39) translates the expression 'adempio' into English as 'decreed'. 
Iago's utterance: 'And I believe man to be / the sport of a wicked fate / from a germ of the cradle / to the worm of the grave. ${ }^{\text {'21 }}$ can be considered a nihilist statement. It is in contrast to the original Christian concept of man (good Christian) as a gardener who sows and then reaps. In Iago's understanding, man is an evil 'entity' of wicked fate full of primeval slime (fango originato) which is within him. The man can even feel its presence. Iago believes that his evil deeds come from within and are based on human nature. Neither God nor fate have authority.

Despite Boito not using Act I of the play, it is of vital importance when searching for conceptual metaphors and their sources in the entire plot. Iago also uses several occasions to develop his conspiracy: he takes advantage of the bad reputation of Venetian women, he misuses the prejudices connected to Othello's different race and nature ('Moors changeable will'), he even takes advantage of Brabantio's warning: 'Look to her, Moor, if thou hast eyes to see: / She has deceived her father, and may thee' (1.2.293-4) etc. The seed of distrust is sown.

In the adaptation of the play, Boito has obviously counted on intertextuality. Not only would they have used the audience's knowledge of the play to their advantage, ${ }^{22}$ but they also had the religious context of society and the knowledge connected to it etc. (especially at the end of the $19^{\text {th }}$ century in Italy).

\section{The fall/CollaPSe Metaphor, the DeStRuction OF the CONTAINER}

The metaphor of FALL/COLLAPSE of the hero is interconnected with the POISON/DISEASE metaphor. In this connection we can take into account the scenography practice of the opera. In many productions of the opera, Otello first appears on stage 'from above', entering upstage. He often appears descending from a ship or from a captain's bridge. From his first moments on stage, Otello is literally positioned in a high place. As a war hero, as the saviour of the people, as the man of honour and distinguished citizen of Venice, he occupies the peak of the hierarchical structure of society. On the conceptual level, Otello enters the container of the island of Cyprus from the outside, from the space occupied by various threats and dangers. At that moment, even the different colour of his skin can be perceived as a distinguishing feature that supports his exclusiveness. It is worth mentioning that the famous 'Esultate' (Rejoice), the first word of Otello's aria on stage and the following parts of his entrance scene, are usually considered to be the vital part of a singer's/actor's performance. Otello's entrance marks the crucial point in the beginning of the plot. He appears when the chorus of Cyprians and Otello's companions cry for God's help during the sea storm. After this scene of horror Otello commands them to 'rejoice' (esultate), to stop worrying about his wellbeing: the positive meaning of the word 'esultate' signifi-

21 'E credo / l'uom giuoco d'iniqua sorte / dal germe della culla / al verme dell'Avel'. Translated by Charles Osborne (1974: 39).

22 Since they could count on the spectator's knowledge of Shakespeare's play they omitted some parts of the original play and even the whole first act of Shakespeare's play. 
cantly supports the initial image of the character as a good man and strong warrior, a saviour.

It is also worth mentioning that sometimes a singer performing this monumental aria is compared with his 'iconic' predecessors in the role, who have set the standard for performance - e.g. Mario del Monaco, or more recently Plácido Domingo, who both represented Otello in various productions of the opera during their professional careers. In the context of particular operatic performance, the 'esultate' moment can be also perceived as the peak of an actor's performance..$^{23}$

It is important to emphasize that Otello appears in his full strength and glory at the very beginning of the story. From this moment on he is incessantly falling. Initially, his fall is slow and barely noticeable. As the story develops the fall becomes more rapid and leads to Otello's fainting in Act III Scene 9. It comes after Otello expresses his thoughts and conclusions motivated by the handkerchief he considers proof of Desdemona's betrayal. After that, Otello's ultimate downfall (death) is inevitable. Just before he faints in the penultimate act, he realises his own 'ill state' when he declaims:

\section{OTHELLO:}

But from myself I cannot fly!

Blood!

Ah! Vile thought!

That grieves me!

(deliriously, convulsively)

The handkerchief!

The handkerchief!

Ah!

(he faints)

IAGO:

My poison is working.

\section{OTELLO:}

Fuggirmi io sol non so...

Sangue!

Ah! l'abbietto pensiero!

ciò m’accora!

(convulsamente, delirando)

Vederli insieme avvinti...

il fazzoletto! ... il fazzoletto! ...

$\mathrm{Ah}$ !

(sviene)

IAGO:

Io mio velen lavora.

(OSBORNE 1974: 69)

Otello recognises his grave illness. The two original stage directions in the libretto are 'convulsamente, delirando' (convulsively, raving). He perceives his JEALOUSY AS DISEASE. Otello's mind is almost shattered at that moment, his body loses its strength, he faints and Iago observes with satisfaction that his 'poison' is working, the CONTAINER is being destructed by POISON. In this crucial moment the difference between the two

23 In his 'Introduction to the libretto', Charles Osborne (1974: 13) gives the following comment on the scene: 'The "Esultate" which so vigorously and immediately establishes Otello's character as a warrior has no counterpart in Shakespeare; it was, in fact, Verdi's idea.' 
metaphorical expressions characterising Otello's evolving state of mind and body are mostly obvious in comparison to other parts of the plot. Otello perceives his state as some kind of illness and looks for the cause within him. But Iago is aware of the fact that the cause comes primarily from outside - from Iago's own 'poison'. Usually a disease runs it's course, it spreads naturally, it's a danger that is brought on through natural/biological circumstances etc. But, poison can be considered a tool that is used or applied by somebody or by something - e.g. a snake. It is therefore used purportedly to cause someone's misery or death. At this moment the contrast between the disease and poison metaphor destroying the hero is of great importance. Otello is still unaware of having been poisoned, and therefore he cannot defend himself against its effects. Of more importance is that he believes he can't defend himself. Iago's INTERACTION with Otello, or more precisely Iago's influence, is conceptualized as a BATTLE. In this battle, the aggressor provokes his opponent's JEALOUSY, fights with POISON that appears to be a DISEASE (or illness), and destroys the CONTAINER of MIND and CONTAINER of BODY from the inside. If Otello was aware of Iago's poisoning, he would probably be able to defeat it with an antidote.

\section{Metaphors in the Opera and in Its Score}

In adapting the play, Boito and Verdi took advantage of the musicality inherent in Shakespeare's work - not only in the implicit sense, but also in the explicit. In the case of Othello, it is manifested in several songs (i.e. in the drinking and willow songs from Act II and V).

In Verdi's opera, music naturally plays a crucial role in developing the dramatic action. This opera is quite often characterised as 'music drama', referring to the development of opera in the $19^{\text {th }}$ century and to Richard Wagner's concept of Gesamtkunstwerk. ${ }^{24}$ In general, Verdi's music for Otello develops and vitally supports the emotive sections. The music helps to describe the image of the characters; it emphasizes and supports crucial situations in the developing story. The music highlights the most important metaphors used in the plot.

The first scene of the opera - the sea tempest - incites strong dramatic tension. The chorus of the citizens of Cyprus, and Otello's co-workers and friends, await in horror for news of their master's fate: they are convinced that Otello is dead. At one moment (when the initial situation of deadly threat is clearly set) the fortissimo dynamic of the orchestra ${ }^{25}$ settles into a pianissimo (but still tense) accompaniment to the chorus, who are singing a prayer (asking God to save their master who may perish at sea). After another tense passage in which Otello's fellows comment on the situation, the orchestra performs a grandiose fanfare leading to the entrance of Otello with his

24 Some scholars (including e.g. above cited Charles Osborne) consider Verdi's style of music drama to be more fruitful for further evolution of opera and they compare it with the 'dead-end' of Wagner's quasisymphonic style that - according to Osborne - produced only other Wagnerians (OSBORNE 1974: 13).

25 Verdi uses e.g. the trumpets alluding to the musical instruments included in Shakespeare's play. 
'esultate'. Everybody celebrates the escape of the hero from almost certain death. After this scene everything is relaxed - even the sound of the orchestra. After the loud and violent sound of the storm, the score becomes much more tempered. Iago launches his scheme in his duet with Roderigo. The following part includes the drinking scene which presents an ideal situation to illustrate Iago's 'poisoning' powers. The scenes of the principles, including Iago, Roderigo and Cassio, are accompanied by the chorus. Although the lyrics of Verdi's drinking scene is different from the songs introduced in corresponding scene of Shakespeare's play, in both works the scene is of vital significance. It can be perceived as a model of Iago's destructive power. Moreover, it provides a model for the development of Iago's scheme. The singing of the chorus represents a joyful frame to the scene. Iago asks Roderigo to help him to encourage Cassio to drink until he gets drunk. Iago sings the main part of this aria. He sings the melody to the others and they repeat his call to drink. The modulation of his voice in his iterative 'beva, beva, beva con me'26 raises the tension with its ascending dynamics supported by other characters, including the chorus and Cassio's high register. At the end of each of his calls to drink, Iago's line descends chromatically by an octave. The increasing alcohol level in Cassio's blood corresponds with the melody which is getting higher and it also becomes louder when he sings his part. The music expresses, or at least supports, the intoxication leading to the fight and total chaos at the end of the aria. The fight is stopped by Otello who appears on stage with his high pitched command 'Abbasso le spade!' (Lower your swords). Otello punishes Cassio, who is degraded. Iago's poison has worked well.

The model of poisoning someone's mind and destroying a person by it is introduced in this critical scene of the opera. Not much later the orchestra plays sinister chords anticipating Iago's evil will and nature. After that, Iago's Credo is made up of a complex thematic structure, which builds dramatic tension.

After the drinking scene and the fight, Verdi introduces the love duet of Otello and Desdemona; who express warm feelings for each other. Metaphorically speaking, another storm is over. The peace displayed in their love duet precedes another storm which proves to be fatal. The duet also introduces the music leitmotiv of their love. This leitmotiv returns in following scenes of the opera, even in the ultimate scene when Desdemona is slayed by Otello.

Many analyses of Verdi's opera have been already written. Besides the analysis of the music, some of them also include the descriptions of the plot in the context of developing dramatic tension. Iago's Credo is often analysed with special interest. For example, Stefan Einsfelder provides a systematic study of the topic in his Zur musikalischen Dramaturgie von Giuseppe Verdis Otello (1994). As for the Credo, he divides the aria into three parts:

[...] Der erste wird begrenzt durch das erwähnte Unisono-Thema und umfaßt 27 Takte. Der zweite Bereich ist 30 Takte lang, in c-moll mit einem an die Eröffnungsszene erinnernden 
Motiv beginnend und mit einem Septnonakkord über Fis endend. Der dritte schließlich ist 21 Takte lang, beginnt mit einer harmonisierten Variante des Unisonomotivs und endet in einer abwärts gerichteten triolischen Brechung eines Sixte-ajoutées über F. (EINSFELDER 1994: 99)

Einsfelder's analytic schema corresponds with the major changes of the mood and of dramatic tension. I shall follow Einsfelder's three-part division of the aria as the basis for my analysis. ${ }^{27}$ The first part begins after the initial recitative and ends in the vocal part with Iago's 'Si!' (Yes!). From the point of view of developing the dramatic tension, Iago provides us with exposition to his worldview including his characterization of himself as a man of evil nature. He expresses his blasphemous relationship to God. Iago's firmly pronounced 'Si!' (Yes!) at the end of the first part is vocalized through the monumental sound of orchestra. The orchestra repeats the initial chords of the aria with strong emphasis. Iago proudly and self-confidently affirms all evil that he's just confessed about himself, and his confession boldly precedes all his subsequent steps. In the second part (as devised by Einsfelder), in a more vivid musical tempo, Iago expresses his worldview with even more details. According to him, all mankind is false and hypocritical, everything that appears to be good is a mere disguise etc. The significance and firmness of these strong words corresponds with culminating melody and dynamics of the music. The orchestral chords of the accompaniment then become softer but the atmosphere remains tense. This marks the division of the second and the third part of Einsfelder's schema. Then Iago sings: 'Vien dopo tanta irrision la Morte' (And after this derision comes death). According to Iago, everything leads to nothingness. He considers death as nothing, the nothingness ('La Morte è' il Nulla'), and 'E vecchia fola il Ciel' (Heaven is an old fable).

As a dramatic monologue, Iago's Credo demonstrates - paradoxically with huge amount of dramatic emotions provided by his singing and the music - the fall into nothingness. No matter what precedes the final inevitable fall, all is but illusion. Iago's Credo can be considered a parallel to the whole story of Otello. Or at least, as a parallel to the effects of Iago's poison.

Recently, Michael Ewans published ${ }^{28}$ detailed analysis of the aria $^{29}$ (2016). He divides Iago's Credo into eight parts (EWANS 2016: 35) and besides other important remarks he describes the dramatic qualities of it which go hand in hand with Verdi's music:

[...] Verdi hears and makes real trough music the sudden mood-changes implicit in Boito's text. Jago moves rapidly and freely from key to key, constantly disrupting expectations, and the orchestra which expresses his feelings and motivation changes texture, dynamics and orchestration just as suddenly. For just one example consider the sixteen bars that follow the start

27 In the following paragraphs I rely on Einsfelder's division, not on his analysis.

28 Despite the fact his book is primarily intended as a 'guide' for singers and directors of opera, his work provides valuable analysis of key scenes from various operas.

29 Ewans also questioned whether the Credo is actually an aria. He concluded - discussing various arguments - that it does not represent an aria in any traditional sense of the word (EWANS 2016: 34). 
of the 'aria' proper, C 7ff. Four bars of octave declamation by the whole orchestra [...] ff tutta forza in F minor are followed by six bars of woodwind and viola trills, which lead Jago to $\mathrm{E}$ flat major. (EWANS 2016: 35)

Ewans considers the trills as the characteristic feature of Iago's vocal line which also appear in other parts of the opera. And in the Credo '[...] their being heard in the orchestra reveals, now that he is alone, his unstable, blasphemous and angry feelings' (2016: 35). Ewans continues with the description of 'furious staccato upward' which 'flourish in the piccolo and violins' and which 'is followed by a semitone shift of key to E major for a new theme forte, aspramente ('harshly') in the strings' (2016: 35). And so forth. In this context Ewans refers to an important comment made by Hepokoski (1987: 145-8) who sees in Verdi's use of tonality as a means of creating 'uncertainty, frequently sending the listener's ears off on a false trail' (HEPOKOSKI in EWANS 2016: 35). This comment also emphasises one of the main 'symptoms' and a working principle of Iago's disease/poison: a confusing of the senses.

In the context of analysing Shakespeare's Othello, some scholars (including above mentioned E. A. J. Honigmann) point out that Othello 'uses' the senses of others especially of Iago. Following Honigmann (2015: 19) it is fruitful to examine the topic of Othello's impaired vision (pp. 17-9). On several examples Honigmann illustrates his claim that 'Shakespeare seems to suggest that Othello sees less clearly than Iago, that he depends on Iago's eyes' (2015: 19). In the play, Othello asks Iago: 'Was not that Cassio parted from my wife?' (3.3.37). This motive is incorporated in the opera. It is not important if Otello's senses are weakened or not, it is Iago who often 'corrects' or '(mis)leads' them, both in the play and opera. It is not only the matter of Otello's sight. Iago manipulates Otello's (and not just his) senses in any possible way. Otello listens to Iago's lies all the time and asks for a 'tangible' proof of Desdemona's betrayal and later he gets it. ${ }^{30}$ Manipulating the senses is the major means of Iago's intrigue. Therefore, Otello's impaired senses can be seen as a 'symptom' of the disease that destroys the hero. Paradoxically, the hero fights the disease which he is aware of with the help of his misled, poisoned senses.

The beginning of Einsfelder's second part corresponds with the beginning of fourth part in Ewans's analysis. Ewans emphasises here how the negative emotions expressed even by the music drive Iago forward (2016: 37). Nevertheless, for the sake of my analysis, which focuses on the metaphors and conceptual metaphors, it is the next part of the monologue which is of interest.

Einsfelder's third part corresponds with Ewans's seventh part of the monologue. When Iago sings 'Vien dopo tanta irrission La Morte', Ewans ascertains that Iago:

[...] peers into the abyss. The powerful octaves which led him to begin Credo [...] are transformed into a descending chromatic sequence, which makes us hear his deepening thoughts

30 Before Desdemona loses her handkerchief she wipes Othello's forehead (to calm him down) with it. Moreover, in some performances the handkerchief appears to contain Desdemona's fragrance since e.g. in the scene where Iago talks about it with Cassio he (Cassio) can smell it. 
as he contemplates the absurdity of life and the inevitability of death. Then silence and more mysterious chords (now $p p / p p p$ for strings alone) surround his contemplation of eternity ('And then? And then?'). The hollow chords descend, dissolve into isolated cello pizzicato, and end in a very low $\mathrm{C} p p p p$ on celli and basses, which as if grudgingly rises to $\mathrm{D}$ flat. Then there is a longer orchestral silence for 'Death is Nothingness'. (EWANS 2016: 37)

Ewans perceives the silence at the end as 'the perfect realization of Jago's nihilistic thoughts' and concludes his analysis with the eighth part of the monologue - the sudden eruption of the orchestra where once again and for the last time the leading emotion of Iago is expressed:

It is accompanied by pounding triplets [...], leading to his final mocking blasphemy, 'Heaven is an old fable!' We hear forte triplets in the cornets and trumpets, [...] tossed out by the woodwind over upper string trills, and a fortissimo tutti climax for the last word of the piece, 'Ciel!'. The orchestra at first presents a thoroughly false assertion of D flat major, which suddenly loses four flats and becomes the 'true' key of F major just after Jago reaches his blazing top F on this word ('Ciel!'). This wrench is a most effective conclusion to an extraordinary few minutes of music theatre. (EWANS 2016: 38) ${ }^{31}$

Ewans - as many other authors including Charles Osborne - sees the main topic of the story in the fighting of the good (represented by Desdemona) and evil (Iago) for Otello's soul (EWANS 2016: 33). In my opinion, this topic can be seen as the key conceptual metaphor in the whole story. ${ }^{32}$ From the point of view of CMT the INTERACTION between Iago and Desdemona can be perceived as BATTLE. The goal is to conquer Otello's mind (soul). Desdemona fights with her kind and careful deeds. Her battle is more defensive. Moreover, she thinks she is fighting against a DISEASE. Therefore, she uses kind words, a handkerchief to cool Otello's forehead, and is ready to give a kiss etc. Iago is an aggressor, yet unrecognized, who fights with POISON.

Since Verdi's Otello is an operatic work it often enters into the multi-media space of theatre. It is a work of art that is performed in three-dimensional space and in time, it uses various means and ways of expressing thoughts, emotions etc. It demands the artists and spectators not only to think but also to use their senses: to engage their embodied minds. The libretto includes basic directions for the staging of the opera. Besides the music (which is an integral component of the work), the scenography represents another component that supports and develops the plot and the conceptual metaphors on which the work is based.

31 It is worth noting that from the point of view of - both its dramatic and musical - complexness Ewans considers necessary to take the initial recitative in the first part as an integral part of the 'aria' or monologue itself.

32 Ewans also emphasises the fact that Boito himself composed the opera Mefistofele. In Otello he connects his skills with a 'composer working for performance in a strongly Christian cultural context' (i.e. with Verdi) (2016: 33). The blasphemous Credo is the breath-taking result of this alliance. 
In describing the stage metaphor, the sea tempest in the exposition of the plot is of great importance. It is the sea tempest that represents the obvious threat to the hero. He aims to get to a place where he can be safe - a CONTAINER. At the beginning of the opera the crucial conceptual metaphor defines the venue. There is a strong tempest at sea, therefore the stage represents the safe place, the demarcated safe zone - a CONTAINER. Above all, it is expressed by the impressive music. As the story reveals everything outside Cyprus (CONTAINER), even strong forces of nature, are not dangerous for Otello. The tempest metaphorically precedes the evolution of the story, but with different results. The initial scene can be comprehended as a conceptual metaphor the THREAT is the TEMPEST. It tries to destroy, or at least partly destroy, Otello's body (CONTAINER). But Otello enters into another CONTAINER to be safe. It is worth adding that from the point of view of demands connected to audience's cognition there is a difference where the sea and the tempest is placed. It is usually depicted by the chorus, more precisely by where the eyes of the chorus members are directed. They can be gazing towards the audience or somewhere around the stage including up- and downstage. Therefore, besides the scenography, the CONTAINER is usually 'created' by the substantial help of the chorus reacting to the music.

Despite the fact that many of the conceptual metaphors are manifested in the text (of both the play and the libretto), they are also expressed by means other than words themselves. For example, in the storm scene of an Otello production, the lighting design represents a very important component. The storm is performed (and perceived) via words, music and visual elements and effects. These often include the flashes produced by lighting. The location of the whole story of the opera on the island of Cyprus provides the roots for the expression of conceptual metaphors by the means of scenography. As the opera opens with an incredibly dramatic scene - a tempest at sea - the stage represents a harbour where the citizens of Cyprus await their master. What is to be set on the stage according to the stage directions of the libretto itself?

The sea can be depicted on stage or, as happens more often, the proximity of the sea is left to the spectator's imagination. The initial scene also requires the chorus to be present on the stage. Lighting design should evoke the lightning of the storm, while Verdi's music expresses the thunder, torrential rain, and wind squalls etc. The storm in the background is expressed through music. The audience is led from the wide exterior of the seashore, where the advancing disaster is displayed, represented by violent force of nature; through the complex conniving schemes of Iago; and finally into the interior - an intimate space represented by the bedroom of a married couple - where human force or violence (led by jealousy and intrigue) creates the real disaster. The scenography of the last scene usually includes a bed with canopy. 


\section{Stage Metaphors in Miloš Wasserbauer's 1967 Production of Otello}

Otello was the first Shakespearian opera by Verdi ever staged at the National Theatre in Brno - it premiered on October 4, 1902, in Divadlo na Veveří (The Theatre on Veveří street). ${ }^{33}$ Verdi operas now represent a regular part of the repertory of the National Theatre in Brno. During the 20th century (and the beginning of the 21st century), a new (or renewed) production of a Verdi opera premiered roughly every two years. ${ }^{34}$

Miloš Wasserbauer (1907-1970) was the oldest, and probably the most successful, director of the 'triumvirate'35 of directors working for the theatre during the 1960s. Wasserbauer worked for the State/Provincial/National ${ }^{36}$ Theatre in Brno during three distinctive periods of his professional career. He staged Verdi's Otello for the first time at the beginning of his career at the theatre in Brno - in 1939. ${ }^{37}$ A year later, in 1940, he directed the production of Benda's singspiel Romeo and Juliet ${ }^{38}$ and in 1941 he directed Verdi's Falstaff. ${ }^{39}$ He directed these productions in collaboration with the scenographer Václav Skrušný. The operas based on Shakespeare's plays mark the start of Wasserbauer's career at the State Theatre in Brno.

In 1967 Wasserbauer directed a new production of Otello between two distinctive productions of Falstaff - directed by his colleagues. At that time, Wasserbauer's Otello was conducted by the outstanding Czech conductor František Jilek, with stage design by Vojtěch Štolfa and costume design by Silvia Barbieri - a guest designer from Milan.

From 1919 until the mid-60s, opera, operetta and ballet troupes of the National Theatre performed in the building of present day Mahen theatre at Malinovský square. In 1965, the three troupes (opera, operetta and ballet) moved to the newly opened Janáček Theatre. ${ }^{40}$ Wasserbauer and his scenographer Vojtěch Štolfa had to deal with new space conditions while preparing the premiere of Otello which took place on 8 January 1967. The change of venue was of vital significance. The old building of

33 The libretto was translated by Václav Juda Novotný. The staging of the operas based on Shakespeare's plays composed by other authors (than Verdi) was quite rare. Only in the 1909 and then in 2013 opera Romeo and Juliet by Charles Gounod was staged. Also in the 2013 A Midsummer Night's Dream by Benjamin Britten was on the program.

During the 20th century even some Czech operatic (or music theatre) adaptations of Shakespeare's plays were staged in Brno. The Tempest composed by Zdeněk Fibich was staged two times - in 1909 and in 1936. The same applies to the 'singspiel' Romeo and Juliet by Jiří Antonín Benda - staged in 1940 and 1978 . It is worth mentioning that the opera has a German libretto by Friedrich Wilhelm Gotter that is based upon Christian Felix Weiße's translation of Shakespeare's play Romeo and Juliet (opera entitled in German: Romeo und Julie).

34 The three Shakespearian operas composed by Verdi appear (in a brand-new production) regularly once or twice in a decade.

35 The other two members of this 'triumvirate' are Oskar Linhart and Václav Věžník.

36 In the course of its history, the theatre changed its name three times.

37 The production was conducted by Quido Arnoldi.

38 Conducted by Vilibald Scheiber.

39 Conducted by Quido Arnoldi.

40 The new building opened with the production of Janáček's The Cunning Little Vixen, directed by Miloš Wasserbauer, conducted by František Jílek, and designed (both costumes and stage) by František Tröster. 


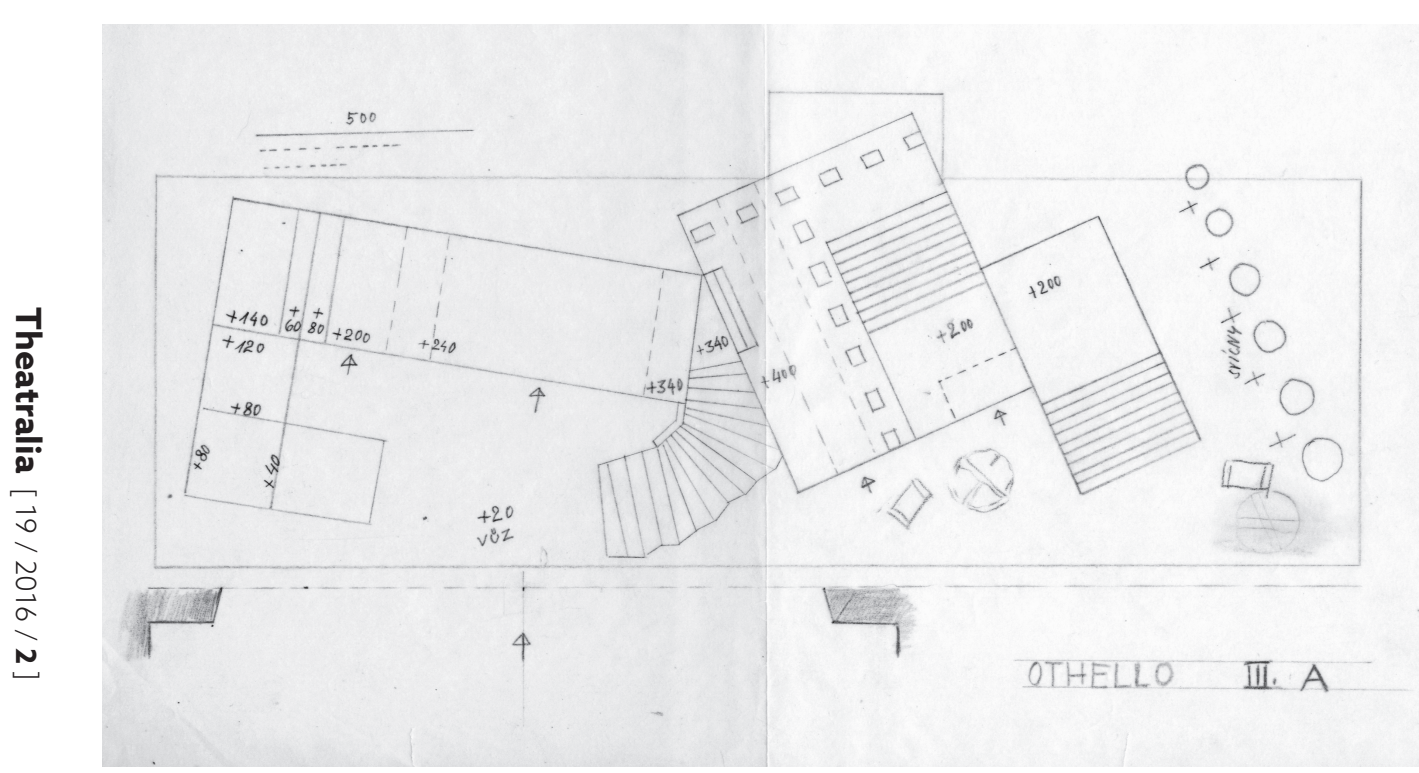

Otello, State Theatre, Brno (1967). Stage plan of set - left section emphasised by proscenium arch; Archive of the Moravian museum, R 564

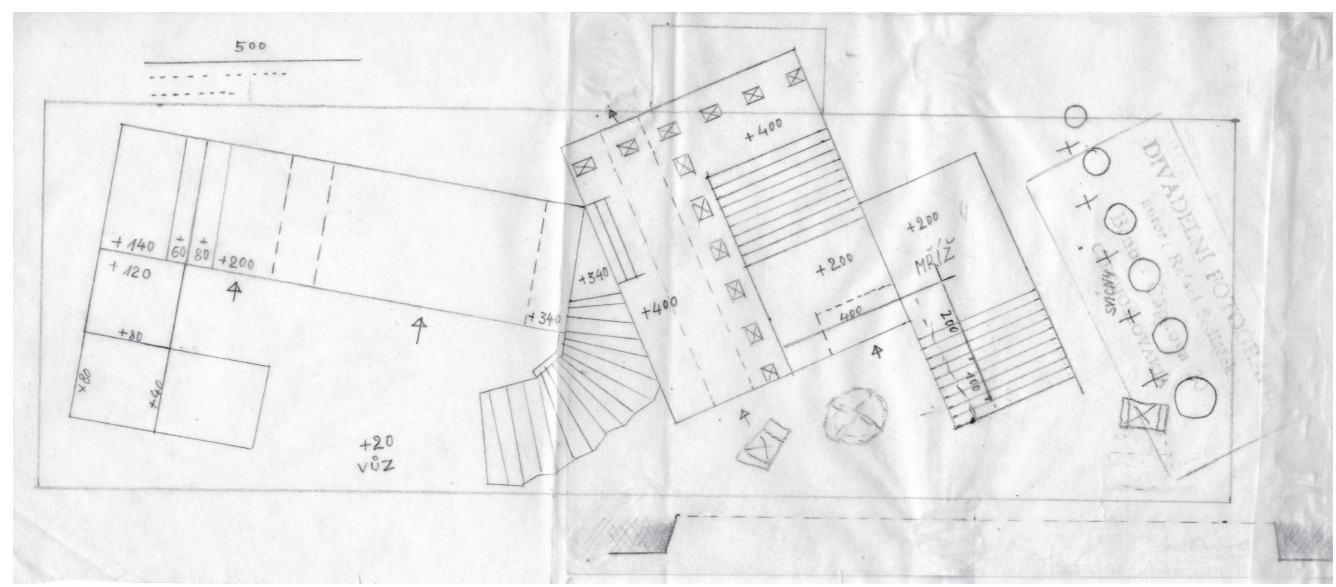

Otello, State Theatre, Brno (1967). Stage plan of set - right section emphasised by proscenium arch; Archive of the Moravian museum, R 564 


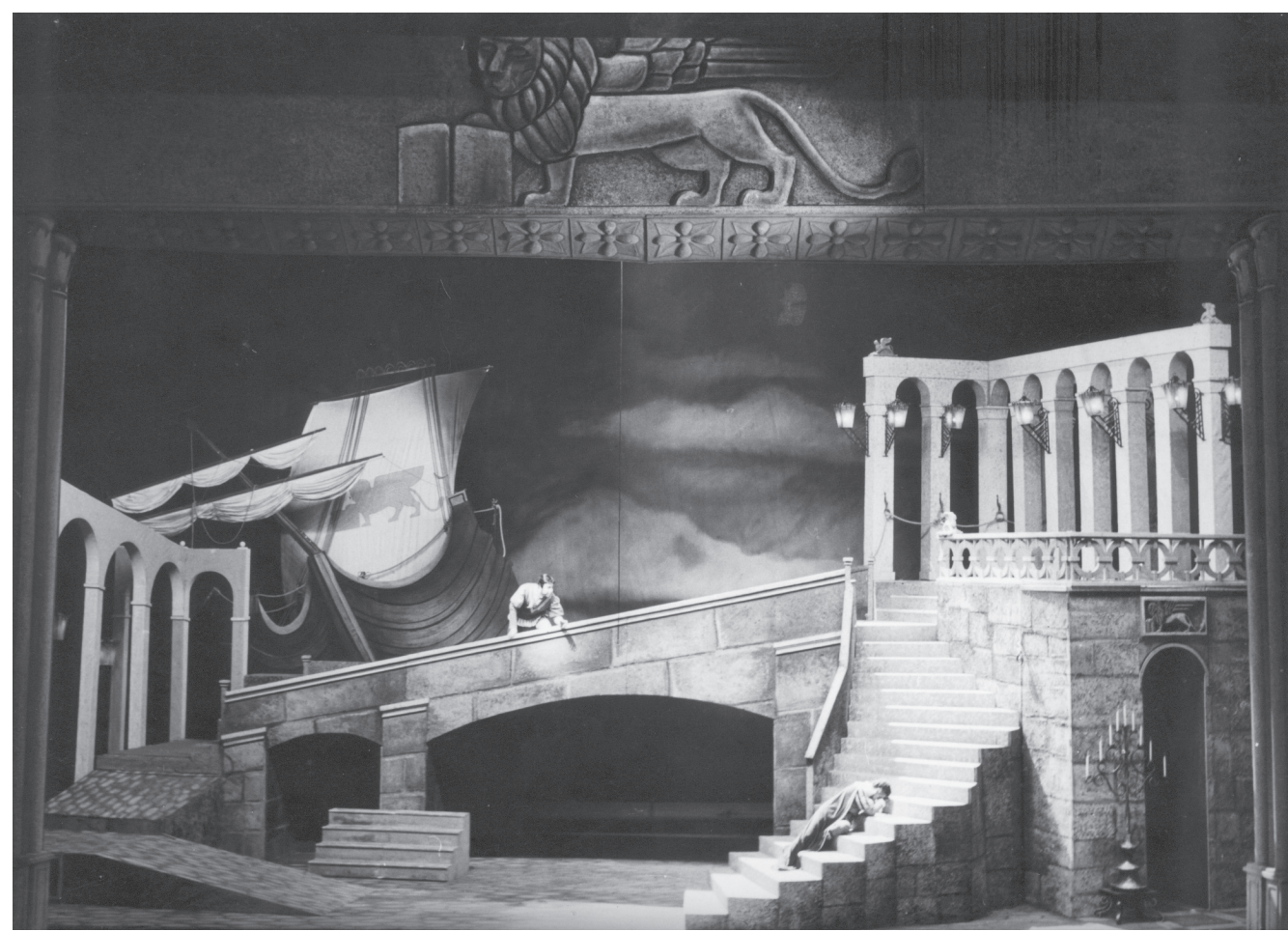

Otello, State Theatre, Brno (1967). Set - left section, with Iago and Otello;

Archive of the National Theatre in Brno, n. 609, Photo @ R. Sedláček

Mahen Theatre (Deutsches Stadtheater) was built in 1882. Its architecture combines Neo-Renaissance, Neo-Baroque and Neoclassical architectural styles. The brand-new building of Janáček Theatre was built in an eclectic style and its architecture is inspired by the opera house in Leipzig ${ }^{41}$. The most important change which influenced the productions was the difference between the stages and the stage equipment in the two buildings. In general, the stage of the Janáček Theatre is bigger and the stage equipment included many technical devices which were very advanced at that time. Even today, some witnesses remember the innovative technical solutions available on the new stage. In 1967, Wasserbauer and Štolfa had the most up-to-date technology at their disposal and they did not hesitate to use it in their scenography for the new production of Otello.

In 2015, in her review of Tosca, Olga Janáčková recalls the 1967 production of Otello. Janáčková mentions the changing scenery which was placed on the wide stage. She emphasizes the vastness of the stage at Janáček Theatre and its potential as far as scenography is concerned. Janáčková describes the impressive shifts of the set from stage left to right. The entire set moved during the fighting scene in Act I.

41 Including e.g. Modernism, Functionalism and Socialist realism. 


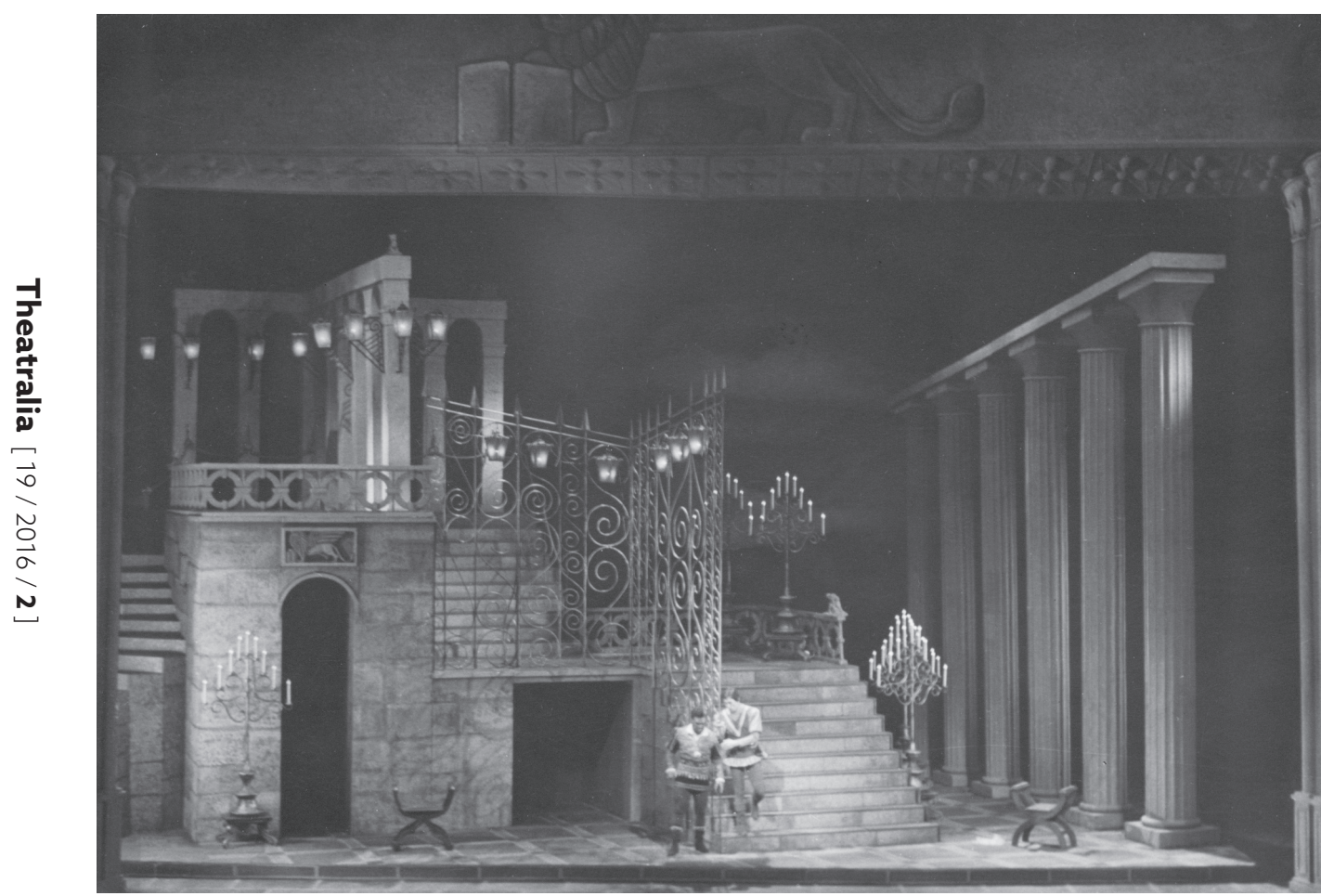

Otello, State Theatre, Brno (1967). Set - central section, with Iago and Otello;

Archive of the National Theatre in Brno, n. 609, Photo (C) R. Sedláček

The main stage of Janáček Theatre is not that much larger than the stage in Mahen Theatre. i.e. the proscenium of the stage in Janáček Theatre is approximately 14 metres wide, just 2 metres wider than Mahen Theatre. The main difference lies in the fact that there are three auxiliary stages in Janáček Theatre connected to the main stage - two side stages and one rear stage.

Obviously, Wasserbauer and Štolfa were aware of the potential of the new stage and its technical options. They based the scenography for the production on a three part set, which was able to shift from one side of the stage to the other side in order to change the scene and to make the action more dynamic. According to eyewitnesses such as Miloš Štědroň, the revolving stage was also used to great effect (ŠTĚDROŇ 1967: 8a).

The stage design of Wasserbauer's and Štolfa's Otello was ingeniously elaborate. The stage drafts and photos kept in the archives (Moravian Museum in Brno, Archive of National Theatre in Brno) show that the set was comprised of three interrelated parts. The vast, asymmetric set was built around three frames which formed the base of the set's structure. ${ }^{42}$ In the course of the performance the three part stage structure shifted

42 The description of the scenography of Wasserbauer's and Štolfa's Otello is based on the following resources: photographs of the performances, photos of the stage itself, stage drafts (included in the piano score, with probably Wasserbauer's own handwritten notes and descriptions of the stage and scenic actions), newspaper articles, eyewitnesses of the productions etc. 
Stage Metaphors in Verdi's Otello: Miloš Wasserbauer's State Theatre Production (Brno 1967)...





Otello, State Theatre, Brno (1967). Set - central section, with Iago and Otello; Archive of the National Theatre in Brno, n. 609, Photo @ R. Sedláček 


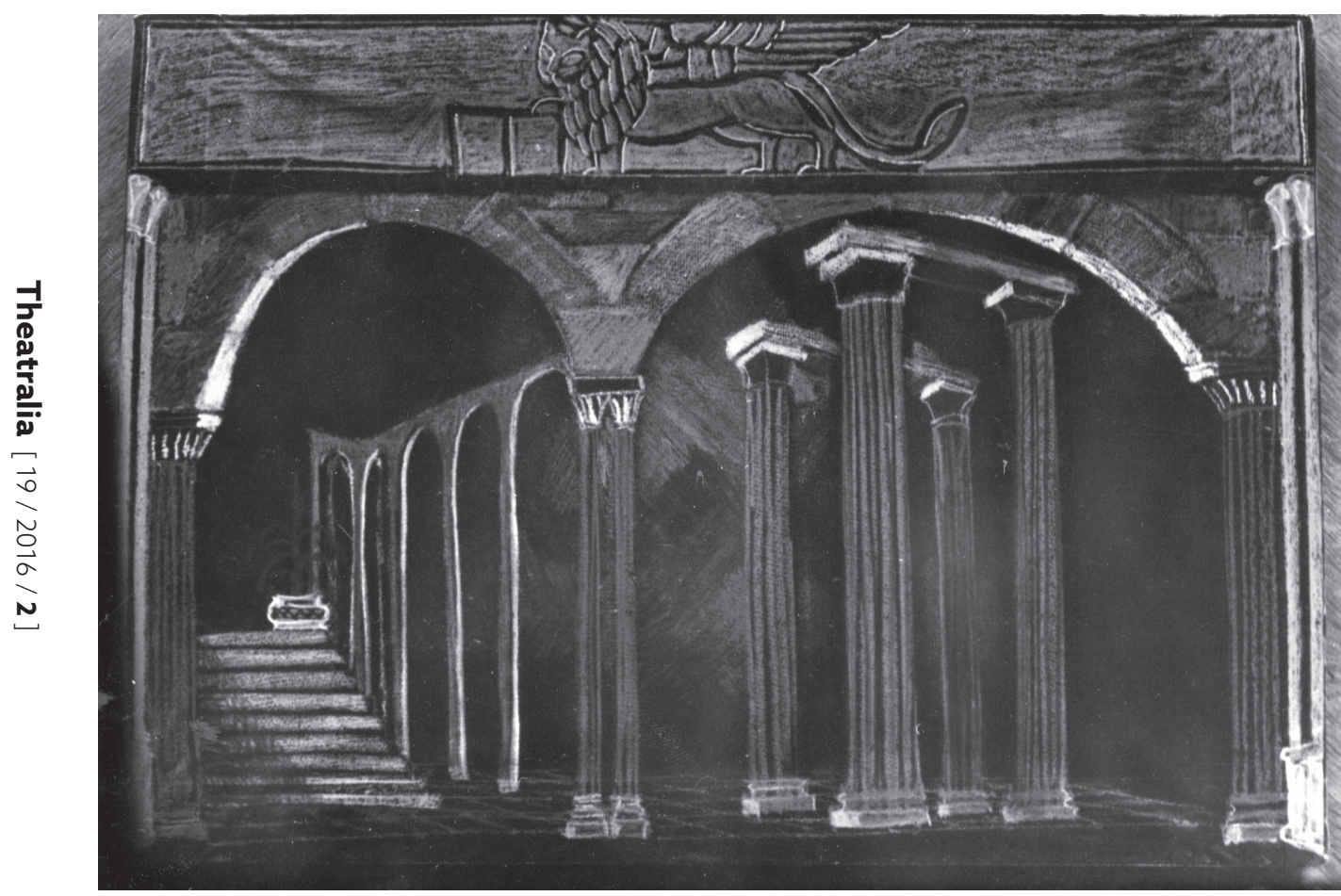

Otello, State Theatre, Brno (1967). Draft of set - right section;

Archive of the Moravian museum, R 564, Photo (c) R. Sedláček

horizontally from stage right to stage left. ${ }^{43}$ The horizontal shifts allowed particular scenes to be displayed to the audience. The scenes were performed from one of the three frames or perhaps even to the space on the boundaries between the frames. Moreover, the revolving stage was used to rotate the scenery when necessary. To give an example, the initial scene of the storm was performed on the first frame (stage right, left section of the set) of the three-frame construction, which was rotated and displayed to the audience during Act I.

The stage construction designed by Vojtěch Štolfa effectively supports the dynamics of the development of the plot. The scenography of the opera was based on big, asymmetric construction. At particular moments, some parts of the wide construction were displayed to the audience, while others remained hidden. The construction consisted of several platforms of different shapes, proportions and heights; placed horizontally in flat or tilted positions. According to the stage drafts, there were also three staircases leading to the higher levels of the construction, one of them partially curved. Various types of banisters, balustrades and columns were also placed on the construction. The stage props included armchairs, lanterns and candleholders, the characters used

43 Considering the photos of the production preserved in the archives, the three dimensional structure shifted not only from the left to the right, but also vice versa according to the development of the story of the opera. 


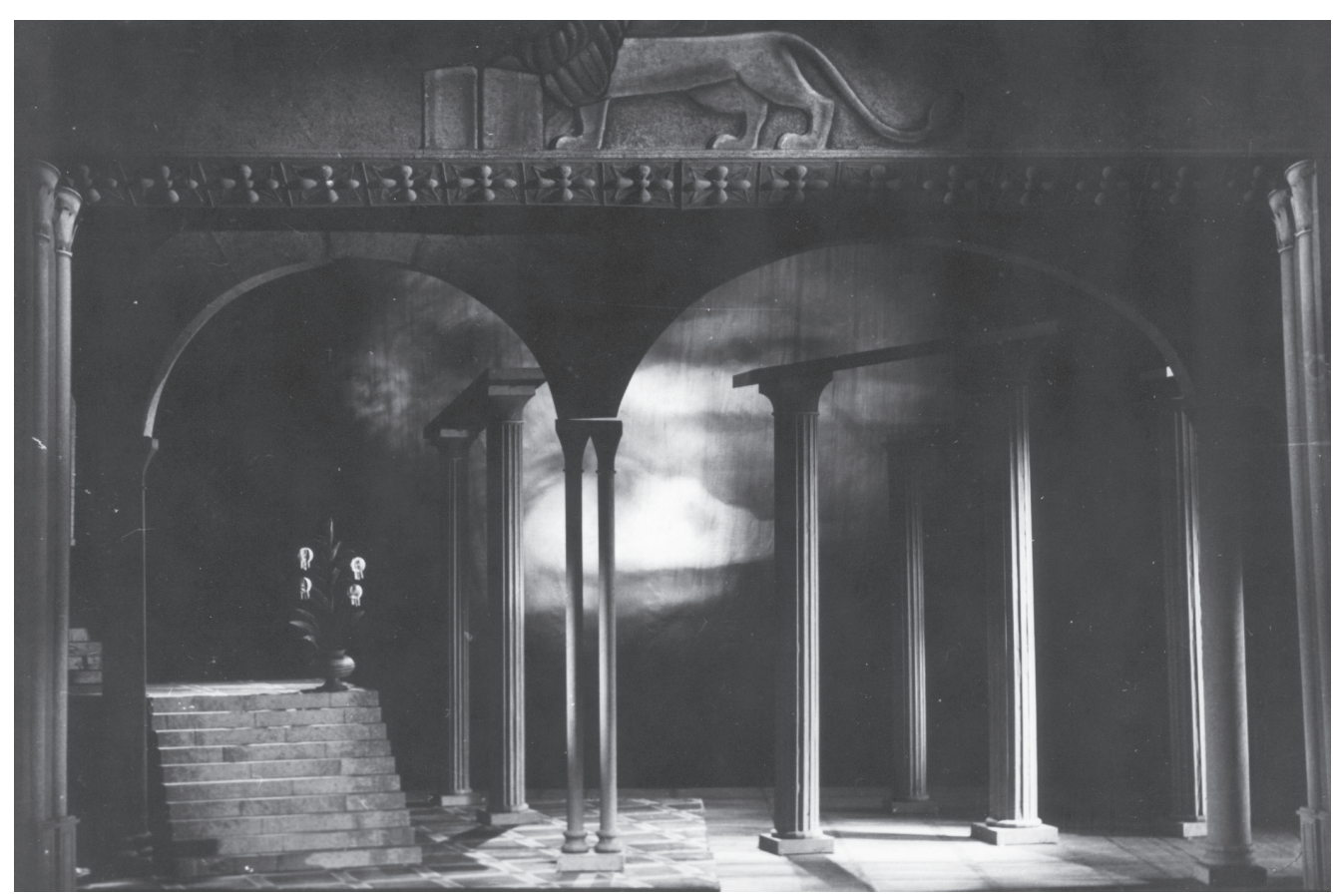

Otello, State Theatre, Brno (1967). Set - right section;

Archive of the National Theatre in Brno, n. 609, Photo @ R. Sedláček

swords etc. The photos of the performances, which are kept in the archives, allow for the conclusion that lights of various types (including candles and torches) were used in the performance.

The proscenium arch (at its top) bore a picture of a winged lion - the symbol of Venice. ${ }^{44}$ The presence of the symbol was derived from the libretto itself. It is included in Montano's first lines of Act I Scene 1 while the chorus identify the symbol on the sail of the arriving ship.

The construction and design of the set enabled the movement of performers in various directions and they could pass through the set via several passageways. It also offered several places where principles (Iago in particular, or Othello, Emilia, Cassio) could hide if the story required it. The option of hiding is enabled by the asymmetrical construction of the set and also by the way the set is set into motion and shifted. The whole dynamics of the stage design strongly supported the increasing atmosphere of uncertainty and confusion of the main character - Otello - and it may have metaphorically expressed the instability and insecurity of the hero's situation.

From this point of view, Štolfa's complex scenography effectively supported Iago's actions on the stage. Not only did Iago always have the option of hiding somewhere, but he was also able to move vertically through the construction of the set. The stage design

44 The symbol is mentioned in the libretto itself and is also mentioned in the part of choir in the very first scene. 
allowed Iago to observe and overlook the events on stage. The set also provided Iago with many discrete places where he could disclose to the audience his inner thoughts and intentions through monologues, as for example he does in his Credo.

These aspects of the set are vital for the development of the story since almost all main characters sometimes need to hide and secretly observe the action of others. All except for Desdemona, who is always seen. Her presence is always apparent to other characters, i.e. her actions are not hidden from the sight of other characters. It is not only Otello and Iago who can observe her actions clearly, but at certain moments Desdemona's actions are also apparent to Cassio (accompanied by Iago), to Roderigo, even to Emilia who becomes witness to the approaching disaster. In every possible way the scenography supported Iago's manipulative 'game' with the senses of the others especially with their sight. The 'game' is played literally in various ways and directions. It is the game of seeing, not-seeing and - above all - seeing (and hearing) something different from what is actually displayed (and heard). And that what is displayed is considered as an illusion or hypocrisy.

As stated earlier, at the beginning of the opera, Otello enters upstage. Archived photos of Wasserbauer's production show us the hero when he entered, descending from a ship. Not only in this particular case, but also in other productions of the opera, the audience can see Othello at the top of the set. Nevertheless, it is Iago who, through his scheming, sets the rules of the story developed on stage. It is Iago who directs what the others can see and hear. This is apparent in the scene of his manipulative conversation with Cassio about Cassio's girlfriend for example. It is Iago who chooses the place where Otello has to hide and directs Otello to the place where he can see and hear the actions of others. He directs Otello's sight and therefore he also directs the mind of the hero towards the garden where Desdemona just said farewell to Cassio etc.

Wasserbauer's and Štolfa's set allowed the characters to pass through it via many passageways. ${ }^{45}$ Iago had access to whichever area of the stage he wanted and needed to be. Literally and figuratively he lead and directed the others through the set, and through the course of the action. If Otello needed proof of Desdemona's infidelity, Iago was able to get the proof and manipulated Otello into seeing it.

Štolfa's and Wasserbauer's scenography of Otello is a very good example of stage design that enables the full development of action that is rooted in the libretto. The scenography echoed the main metaphors and conceptual metaphors - particularly OTELLO'S STORY IS FALL, HOME/BODY/MIND IS CONTAINER to be destructed, and JEALOUSY IS POISON and can be perceived as a fatal DISEASE - and enabled them to fully evolve.

As with most Otello productions of the 1950s and 1960s, Štolfa's scenography is based on architectonic set construction referring metaphorically to the Italian Renaissance. Although the architecturally expressed metonymy (or more precisely synecdoche) differs in each particular production, some basic elements are always the same: the set usually includes passageways, decks or stages of different shape and height. Steps and

45 Considering the presence and movement of the chorus, multiple gate-ways contribute to their fluent and even quicker movement - also on and off stage. 


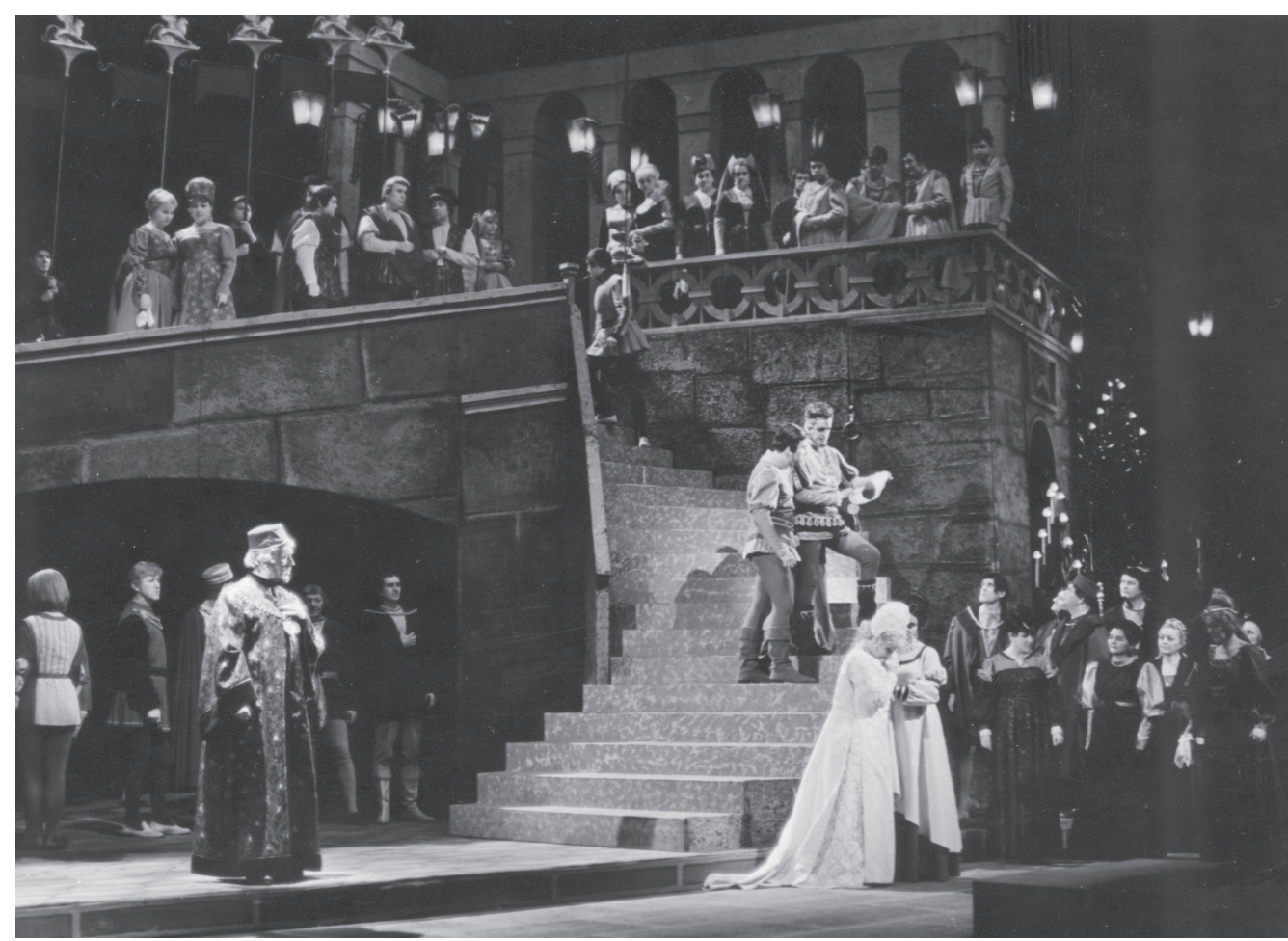

Otello, State Theatre, Brno (1967). Set - left section, with principals and chorus; Archive of the National Theatre in Brno, n. 609, Photo @ R. Sedláček

staircases of different types are also of vital importance in Otello productions. They allow for a dividing of the stage vertically and also allow access to different levels of the set. Moreover, they provide areas which are independent from the main acting space etc. The vertical differentiation of the set is of special importance for Otello, since it enables, through scenography, to conceptualize the fall of the hero (or, through the viewpoint of the conceptual metaphor, the gradual destruction).

In his scenography for Otello, Štolfa designed a complex architectonic stage structure that also contained the above mentioned sets of tilted horizontal platforms. These platforms were placed mostly on stage right of the first stage frame. The platforms slowly rose towards the top of the set, leading towards upstage left. Such a tilted platform could be seen as part of the big bridge (also tilted) which was placed upstage of the first frame. Below the bridge there was a passageway. In Act I, the passageway allowed access backstage. In the other acts it allowed the characters to pass through the set or it provided them with a convenient hiding place.

For Act III, the set was shifted and allowed the audience to see another part of the scene. The spectators could now see three staircases. One staircase could be seen stage right, the other two stage left. They all lead to the upper level of the stage (stage right), and allowed access to a platform with pillars which resembled a balcony. Below the 


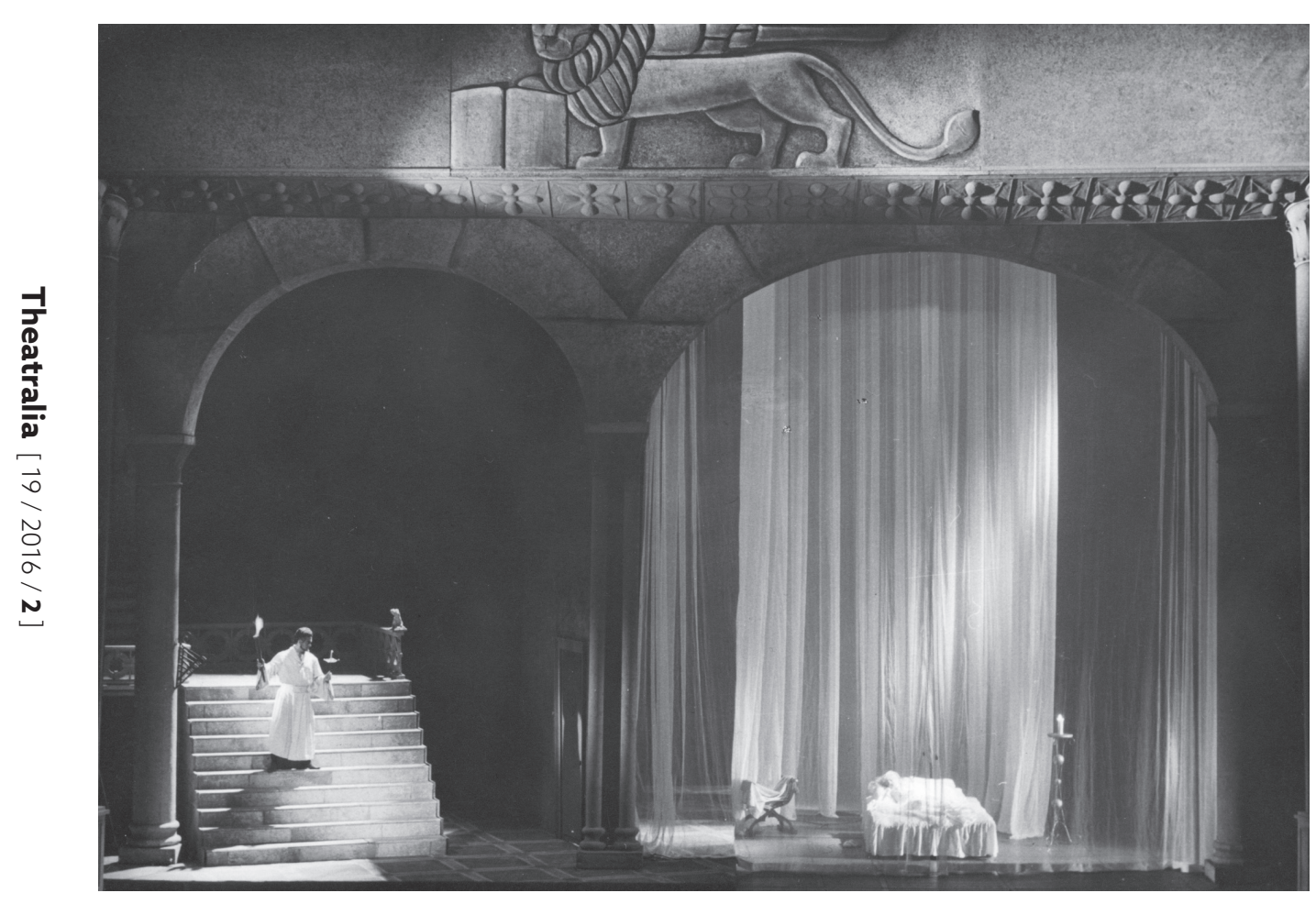

Otello, State Theatre, Brno (1967). Set - bedroom - right section;

Archive of the National Theatre in Brno, n. 609, Photo @ R. Sedláček

balcony, there were doors to the passageways and a small passageway leading upstage. In the last scene of the opera the set was shifted once again and allowed the audience to see the construction from another angle. This time the audience could see only one of the staircases on stage right. Otello descends to the bedroom where Desdemona lay in a beautiful canopy bed and awaited the hero and his - or rather their - inevitable final fall. The canopy bed was the only element on stage that was not visible until the final scene.

Štolfa's stage design was literally based on changing perspectives. It took advantage of the stage equipment including the revolving stage which allowed the set to be revealed to the audience from various angles. This change of viewpoint supported the majority of action on stage. The scenography changed and developed along with the plot and helped to conceptualize the world of Otello's story.

The winged lion of Saint Marc, the symbol of Venice, is the only element which remained unchanged during the performance. It was firmly placed at the top of the stage frame. The lion was literally present above all the action and it provided a frame for the whole story. 


\section{Conclusion}

Not only Shakespeare's plays, but also their operatic adaptations, encourage theatre artists to let 'the Bard' speak or sing in highly dramatic, artistic and spectacular ways. Verdi's Otello is still very popular on world opera stages. Both authors comprehended and further elaborated the key conceptual metaphors of the plot of Shakespeare's play. They were able to express the key metaphors through various means. All productions that followed the very first staging of Otello always had to deal with the task of comprehending the plot on a conceptual level. Such conceptual comprehension allows productions to successfully express and communicate the ideas or 'message' of the story to the audience. The concept of strong and 'healthy' hero poisoned through his senses by the disease called 'envy' or 'jealousy' (JEALOUSY IS DISEASE) that leads to his fall serves as a basis for developing the story. That is also the basis for its understanding. Iago is envious of Othello and he poisons the hero, infecting him deliberately. The threat of the destructive disease is the topic of vital importance and therefore it has strong dramatic potential. Iago's evil deeds, which he performs with the goal of destroying his enemy, represent a complex topic. It can be understood through strong metaphors which are present in the story. A theatrical stage provides a space where the story can be effective if the key metaphors are processed by the artists and the audience at the conceptual level. The theatre has many ways and means of expressing and making the abstract domain of human emotions concrete. Not only through verbal expressions but also by means of scenography and music. The theatre helps us to understand the meaning of the story since the spectator can involve his or her own experience with the real world. The metaphors in the story reverberate in the human mind since everybody has, at least once, fought against a disease and can therefore use his or her own life experience. Because of that, these metaphors are not mere figurative or poetic expression(s). They are rooted firmly in both the texts and in their conceptual base. It can be clearly shown on many concrete examples. These examples include single words and sentences (poison etc.), situations (of spreading a disease), music motives and even the plot itself.

\section{Bibliography}

BALATKA, Antonín. 1939. Otello. (Programme to the production). Brno: Městské divadlo v Brně, 1939.

EINSFELDER, Stefan. 1994. Zur musikalischen Dramaturgie von Giuseppe Verdis Otello [Towards Music Dramaturgy of Otello by Giuseppe Verdi]. Gustav Bosse Verlag, 1994.

EWANS, Michael. 2016. Performing Opera. A Practical Guide for Singers and Directors. London: Bloomsbury, 2016.

HAVLÍČKOVÁ KYSOVÁ, Šárka. 2015. Interview with Václav Věžnik. Digital recording from 7 December 2015 stored in Havlíčková Kysová’s personal archive. 
HEPOKOSKI, James A. 1987. Giuseppe Verdi: Otello. Cambridge: Cambridge University Press, 1987.

HONIGMANN, E. A. J. (ed.). [1997] 2015. Othello. Arden Shakespeare. Bloomsbury, 2015.

JANÁČKOVÁ, Olga. 2015. Tosca v katedrále [Tosca in the Cathedral]. Opera Plus, 17. 5. 2015. [accessed 22 Sept 2015]. Available on http://operaplus.cz/tosca-v-katedrale/.

JOHNSON, Mark. 1987. The Body in the Mind. Chicago: The University of Chicago Press, 1987.

KRANZ, Dieter. 2008. Interview with Walter Felsenstein on production of 'Othello'. 10. 10. 1959, Berliner Rundfunk (excerpts). In Walter Felsenstein Edition. Giuseppe Verdi Othello. DVD 2. Arthaus Musik GmbH, 2008.

LAKOFF, George and Mark JOHNSON. 2003 [1980]. The Metaphors We Live By. Chicago: The University of Chicago, 2003.

MCCONACHIE, Bruce. 2003. American Theater in the Culture of Cold War. Producing and Contesting Containment, 1947-1962. Iowa: University of Iowa Press, 2003.

OSBORNE, Charles. 1974. Verdi e L'Otello [Verdi and the Othello]. EMI, 1974.

ŠTĚDROŇ, Miloš. 1967. Othello, jak má být... [Othello as You Like Him]. Mladá fronta, Ostrava (25. 1. 1967): 8a.

ZÁMEČNÍK, Evžen. 1989. Otello. (Programme to the production). Brno: Státní divadlo v Brně, 1989. 


\section{Summary}

\section{Stage Metaphors in Verdi's Otello: Miloš Wasserbauer's State Theatre Production (Brno 1967) in the Context of Otello's Staging Tradition}

The article deals with the stage metaphors of Verdi's Otello with particular interest in the 1967 Brno production, directed by Miloš Wasserbauer. The main metaphor discussed is that of containment. The author compares Wasserbauer's interpretation with former and later productions depicting the main stage metaphors. The first part of the article deals with the stage metaphors inherent in both Boito's libretto of Otello and in Shakespeare's Othello. The second part of the article focuses on essential elements of staging which are rooted in Otello (including the score). The third part analyses the staging practice of Otello with special regard to Wasserbauer's production. The methodological apparatus of the article is inspired by the Conceptual Metaphor Theory (CMT).

\section{Keywords}

Verdi, Boito, Otello, Shakespeare, Wasserbauer, Štolfa, Jílek, metaphor, stage metaphor, Conceptual Metaphor Theory, Cognitive Theatre Studies

DOI: 10.5817/TY2016-2-2

\section{Šárka Havlíčková Kysová, Ph.D. \\ Masaryk University, Brno, Czech Republic \\ E-mail: sarka.havlicek@mail.muni.cz}

Šárka Havlíčková Kysová received her PhD from Masaryk University, Brno in 2010 with the doctoral thesis Hastaabhinaya. Hand gestures in traditional theatre art of India. From 2009 to 2012 she taught theatre theory at Palacký University in Olomouc. From 2011 to 2015 she worked on two Masaryk University research projects; 'Czech Structuralist Thought on Theatre: Context and Potency' and 'Operational Programme Education for Competitiveness - 2.2 Higher Education'. Since 2012 she has worked as assistant professor at the Department of Theatre Studies at Masaryk University. In her research and teaching, she focuses on theatre theory with an emphasis on the cognitive approach in theatre studies. She also specialises in opera staging and the traditional Indian theatre form - Kootiyattam. Since 2015 she has lead the research project 'Generation of Miloš Wasserbauer, the theatre director, and progressive dramaturgy of State Theatre in Brno' which is focused on operatic productions in Brno in the second half of the 20th century (supported by the Czech Science Foundation project No. GA15-06548S). 